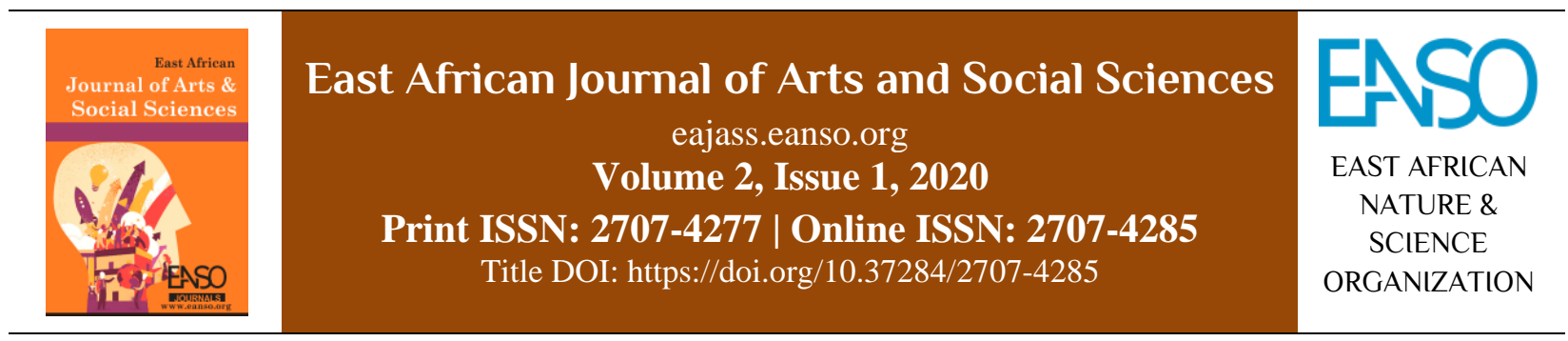

Original Article

\title{
Impact of Public, Private and Non-Governmental Organisations' Financial Interventions on Youth Livelihood Outcomes in Kenya
}

\author{
Lucy W. Ngige, $P h D^{1 *} \&$ Christine W. Njuguna, PhD \\ ${ }^{1}$ Kenyatta University, P. O. Box 43844 - 00100, Nairobi, Kenya; ORCID: https://orcid.org/0000-0003-1750-1496. \\ ${ }^{2}$ Kenyatta University, P. O. Box 43844 - 00100, Nairobi, Kenya; ORCID: https://orcid.org/0000-0001-7173-0498. \\ *Author for Correspondence email: ngigelucy@gmail.com.
}

Article DOI: https://doi.org/10.37284/eajass.2.1.204

\section{Article history: ABSTRACT}

30 August 2020

Keywords:

Public,

Private,

Non-Governmental

Organisations,

Start-Ups,

Financial Interventions, Youth Self-Help Groups,

Youth Livelihood

Outcomes.
This study investigated the impact of public, private and Non-Governmental Organisations' financial interventions on youth livelihood outcomes (YLO) in Kenya. A survey of 201 respondents randomly sampled from registered Youth Self-Help Groups in Nairobi County was conducted. Results showed that males constituted $74 \%$ and females made up $26 \%$ of the sample. The ages of the respondents ranged from 18 to 35 years. The results for livelihood outcomes indicated that $52 \%$ of the youth were at a survival level, $18 \%$ were at the security level and 30\% were at the growth level of youth livelihood outcomes. Hypothesis test results further revealed that there was a relationship between the financial interventions and youth livelihood outcomes $\left(\chi^{2}=18.70\right.$; d.f. $=7$; $\mathrm{p}<0.05)$. Further regression results revealed three significant predictors of YLO in rank order as the public devolved funds comprised of Youth Enterprise Development Fund and Uwezo Fund $(\beta=0.761 ; \mathrm{p}=0.009)$, followed by private micro-finance institutions $(\beta=1.003 ; p=0.010)$ and finally, informal loans provided to members of Youth Self-Help Groups $(\beta=1.037 ; p=0.018$. The variables that were not significant predictors of YLO were Non-Profit Organisations, Faith-Based Organisations and Community-Based Organisations' financial interventions. These findings implied that government-sponsored devolved funds had the greatest impact on youth livelihood outcomes, followed by funding by private micro-finance institutions and finally informal loans provided by the youth self-help groups to their members. This study has established that the public, private and the youth selfhelp groups' financial interventions had the most significant positive impacts on youth livelihood outcomes. It was recommended that there was a need to provide more youth-targeted financial interventions by both the public and the 
private sectors in order to enhance youth livelihood outcomes. Furthermore, active participation by the youth in their development process is paramount for sustainable livelihoods to be achieved.

\section{APA CITATION}

Ngige, L., \& Njuguna, C. (2020). Impact of Public, Private and Non-Governmental Organisations' Financial Interventions on Youth Livelihood Outcomes in Kenya. East African Journal of Arts and Social Sciences, 2(1), 73-86. https://doi.org/10.37284/eajass.2.1.204

\section{CHICAgO CITATION}

Ngige, Lucy, and Christine Njuguna. 2020. "Impact of Public, Private and Non-Governmental Organisations' Financial Interventions on Youth Livelihood Outcomes in Kenya". East African Journal of Arts and Social Sciences 2 (1), 73-86. https://doi.org/10.37284/eajass.2.1.204.

\section{HARVARD CITATION}

Ngige, L. and Njuguna, C. (2020) “Impact of Public, Private and Non-Governmental Organisations' Financial Interventions on Youth Livelihood Outcomes in Kenya", East African Journal of Arts and Social Sciences, 2(1), pp. 73-86. doi: 10.37284/eajass.2.1.204.

\section{IEEE CITATION}

L. Ngige and C. Njuguna, "Impact of Public, Private and Non-Governmental Organisations' Financial Interventions on Youth Livelihood Outcomes in Kenya", EAJASS, vol. 2, no. 1, pp. 73-86, Aug. 2020.

\section{MLA CITATION}

Ngige, Lucy, and Christine Njuguna. "Impact of Public, Private and Non-Governmental Organisations' Financial Interventions on Youth Livelihood Outcomes in Kenya". East African Journal of Arts and Social Sciences, Vol. 2, no. 1, August 2020, pp. 73-86, doi:10.37284/eajass.2.1.204.

\section{INTRODUCTION}

According to the United States Agency for International Development (2013) and the United Kingdom Department for International Development (DFID, 1999), youth-targeted financial interventions are a part of the important transformative structures and processes that provide an enabling environment for youth to derive their livelihoods. These interventions can be in the form of social networks such as the youth self-help groups and initiatives by public, private and Non-Governmental Organisations (NGO) actors. The existing youth policies that guide development actors as they formulate the financial interventions are critiqued as having failed (Omolo, 2011). There is a growing recognition by many governments of the need for policies on youth livelihoods to address economic and employment challenges (United Nations Economic Commission for Africa (2010) and African Union Commission (2006). There is a need to make a clear distinction between policies that are not specific to youth but nonetheless benefit the youth, and those that specifically target young people.

In Kenya, Omolo (2011) and Ogolo (2009) reported that youth policies have focused on public works programmes, entrepreneurial development and skills improvement. Policies are also gender biased towards male youth who are more involved in income-generating activities that are more easily identifiable and supported. As for female youth, they are confined in their domestic spheres (Omolo 2010; Ogolo 2009), a concern which warrants an understanding of the plight of livelihood outcomes across both genders in view of these revelations. For many decades, there was an assumption by nonstate actors focusing on youth that the private sector growth would continuously provide jobs. This resulted in many non-state interventions having a bias on education and training programmes that prepared youth for the workforce and higher education. However, these interventions only benefitted some youths, whereas job creation by the private sector has not measured up to the demands 
of a growing youth population (United Nations Development Program [UNDP] 2010).

In addition, there exists a gap in the evaluation of financial interventions on livelihood outcomes in developing countries. Studies by Njonjo (2010) and Cunningham, Sanchez-Puerta and Wuermli (2010) found out that in Asia, Middle-East, North Africa and Sub-Saharan Africa, only $10 \%$ of programmes targeting youth had evaluation systems that addressed impact and cost. Moreover, they posit that this problem was prevalent in programmes dealing with subsidized employment schemes and entrepreneurship. Knowledge gaps in intervention programmes targeting youth exist in "second chance" education for those who drop out of formal school in search of skills certification, microfinance and technology-based job search assistance.

According to UNDP (2013), there is a shift towards the development of the livelihood of youth from marginalized backgrounds compared to those in the formal sector. Research shows that the core driver of positive youth outcomes in areas of health, education, democracy and governance is livelihood development. Youth livelihood programmes focusing on the majority of youth from marginalized backgrounds and in the informal sector realize that interventions must help youth from where they are until they break into the formal sector. At the same time, these programmes should aim to improve the short-term well-being of youth and their households. Among the public development interventions targeting the Kenyan youth is the introduction of devolved funds (Ogolo, 2009). Kenya has a number of devolved funds accessible to the youth, for example, the Youth Enterprise Development Fund (YEDF), Uwezo Fund, Women Enterprise Fund (WEF), District Poverty Eradication Commission Revolving Fund, and National Development Fund for Persons with Disability (NDFPWD), Constituency Bursary Fund, Free Secondary Education Fund (FSEF) and Community Development Trust Fund. Kiraka, Kobia and Katwalo (2013) reported that the state endeavoured to promote a culture of entrepreneurship of micro and small (MSEs) enterprises through the creation of new start-up funds to improve social-economic wellbeing of populations in all counties.

\section{Public Financial Interventions}

The Youth Enterprise Development Fund (YEDF) is a state corporation under the Ministry of Public Service, Gender and Youth Affairs. It was gazetted on 8th December 2006 and then transformed into a State Corporation on 11th May 2007. The Fund is one of the flagship projects of Kenya Vision 2030, under the social pillar. Its focus is on enterprise development as a key strategy that will increase economic opportunities for, and participation by Kenyan Youth in nation-building. The YEDF seeks to create employment opportunities for young people through entrepreneurship and encouraging them to be job creators and not job seekers. It does this by providing easy and affordable financial and business development support services to youth who are keen on starting or expanding their businesses (YEDF, 2006). According to Maisiba and Gongera (2013), YEDF plays a critical role in job creation in Kenya. This fund is channelled through financial intermediaries such as commercial banks, Savings and Credit Cooperatives (SACCOs), and Micro Finance Institutions (MFIs). Youth can access this fund directly either as individuals or as self-help groups, cooperatives and companies. YEDF is mandated to increase capital base among youth who are entrepreneurs, promote medium, small and micro enterprises (MSMEs) investments, facilitate marketing of products and services by youth, offer business development services to youth and source employment opportunities for youth from local and international labour markets.

Uwezo Fund was launched in 2013 as a flagship project of Kenya's blueprint Vision 2030, targeting vulnerable groups namely: women, youth and persons with disability). The fund operates at the 
constituency level and is mandated to enhance financial access for youth and women in business in line with Vision 2030 economic pillar (Uwezo, 2014). Youth groups applying for Uwezo fund are required to be registered with the social services department or registrar of societies, members must be aged 18-35years and operating at the constituency level. The self-help groups must have evidence of monthly contributions under a table banking model and a bank account. The minimum amount the youth can access is Kenya Shillings fifty thousand (KSh. 50,000) while the maximum is half a million (KSh. 500,000), (Uwezo, 2014). (Note One (\$1.00) United States Dollar is equivalent to 100 Kenya Shillings) in 2020.

\section{Private Financial Interventions}

According to Njuguna (2016), there is a variety of financial institutions such as commercial banks and microfinance institutions in Nairobi County. Financial institutions provide information and facilitation for bank accounts opening, access to credit and statements of account, loans, automated money services, mobile banking and training on financial literacy. Financial institutions have also made remarkable strides in developing tailor-made products and services for the youth in Kenya. These financial interventions meet some of the need for savings and credit facilities among the youth. However, the financial interventions from commercial banks have been targeted on the upper income and middle-income brackets at the expense of the lower segment of the pyramid. A survey by FinAccess (2009) indicated that youth under 25 years of age constituted $68 \%$ of Kenya's population, and, had the highest exclusion rate in reference to formal financial products and services. This hitherto excluded the low-income youth group commonly referred to as the "unbankable" youth from accessing start-up loans from traditional financiers. This gap in financing the marginalized youth became an opportunity for the mobile-based banking services from Safaricom Limited, Airtel Limited and various commercial banks. The mobile financial service providers perceived an opportunity upon realizing that a significant majority of youth across all income groups own a mobile phone device. Products developed under this platform now enable youth to access information, open an account, deposit money, withdraw, transfer, pay bills, and acquire loans. These loans are acquired with convenience and ease without requiring the low-income youth to own a bank account or to have collateral to access loans.

\section{Non-Governmental Organisations' Financial Interventions}

According to Lewis and Kanji (2009), NonGovernmental Organisations (NGOs) are critical actors in the development efforts in developing countries. NGOs are defined as self-governing, not-for-profit organisations whose mission is to enhance the quality of life of marginalized groups in a local community. NGOs are neither run by the government nor driven by profit like the private sector. NGOs can be grouped into two main types, either secular or faith-based organisations. There are a myriad of NGOs in the world, however, this study focuses on those NGOs that promote livelihood outcomes. These include Non-Profit Organisations (NPOs), Community Based Organisations (CBOs) and Faith-Based Organisations (FBOs) in the study area. The main role of NGOs in Kenya is service delivery to disadvantaged groups at the community level. NGOs are recognized as having a significant impact on disadvantaged groups as well as the local community development outcomes. In terms of funding, NGOs are either funded by donors or they mobilize their resources locally.

Other types of NGOs are Savings and Credit Cooperatives (SACCOs) and Rotating Savings and Credit Associations (ROSCAs). According to Atsiaya (2020), SACCOs are user-owned, usercontrolled and user-benefitting organizations. These NGOs fall under institutional-based SACCOs, community-based SACCOs and 
religious-based SACCOs. A Savings and Credit Co-operative is an autonomous association of people united voluntarily to meet their common economic, social and cultural needs and aspirations through a jointly-owned and democraticallycontrolled enterprise. The basic mandate of SACCOs is to mobilize savings and deposits, provide diversified financial products and services, maximize returns on savings to stakeholders, facilitate investments and promote partnerships for wealth creation. According to Siwan and Baland (2002), ROSCAs constitute one of the most commonly found informal financial institutions in the developing world. ROSCAs are known by many different names, such as Chama in Kenya and Upatu in Tanzania. ROSCAs are particularly prolific in Africa, where they have exceptionally high membership rates of between $50 \%$ and $95 \%$ of the adult population. In many developing countries, these associations are the sole savings and credit institutions available to the majority of the population.

According to Njuguna (2016), Nairobi County has a wide range of non-profit organisations such as Ghetto Foundation, Eastleigh Community Center (ECC), Undugu Society, Nairobi Network, Consortium of Youth Groups, Family Health Options Kenya, USAID - Kenya Transition Initiative (KTI) and Pumwani Youth Group Network (PYGRON). These NGOs provide an array of youth-targeted interventions to complement the public and private sector development efforts aimed at enhancing sustainable livelihoods for the youth. According to USAID (2012a; 2012b; 2013), we can relate development interventions to outcomes, whereby the latter has been viewed as a result that is expected to have a change and positive impact on the targeted community youth. There is growing evidence that holistic youth-targeted interventions are achieving greater impacts in developed countries. However, there is a gap in knowledge on the impact of public, private and NGO financial interventions on youth livelihood outcomes in developing countries. Therefore, there is a need to establish the factors associated with livelihood outcomes for youth in Kenya.

\section{Youth Livelihood Outcomes}

According to Mc Kee (1989), livelihood outcomes occur along a continuum of three levels namely: survival, security and growth levels. Survival livelihood level is achieved when a household primary concern is the attainment of basic needs. Security livelihood level occurs when a household diversifies its livelihood strategies intending to reduce risk and shocks and increase flexibility. Growth livelihood level occurs when a household can invest in more capital-intensive livelihood strategies such as microenterprise production activities and get higher profits and where significant investment is required. This study adapted McKee's (1989) three classifications of youth livelihood outcomes. There is scanty documentation on the factors that influence youth livelihood outcomes in Kenya. Therefore, the purpose of this study was to investigate the impact of public, private and non-governmental financial interventions on youth livelihood outcomes. The objectives of the study were to: (1) establish whether there was a significant impact of public devolved funds (YEDF and Uwezo Funds) and youth livelihood outcomes, (2) determine whether there was a significant impact of private financial interventions and youth livelihood outcomes and (3) determine the extent to which NGOs financial interventions influenced youth livelihood outcomes in Kenya. The null hypothesis stated that public, private and NGO financial interventions had no significant impact on youth livelihood outcomes.

\section{METHODOLOGY}

A survey was conducted among 201 randomly selected respondents who were members of registered youth self-help groups in Nairobi County, Kenya. A structured questionnaire was used to collect data. The independent variables 
were represented by the uptake of public, private and non-governmental organisations' start-up financing among the respondents. For the purpose of establishing the independent variables scores of responses to six questions along a 3-point Likert type scale were calculated. The questions assessed the uptake of different sources of funds to support youth livelihood strategies in the previous year. Responses on the scale were coded as: " $1=$ Little Extent", " $2=$ Moderate Extent" and " $3=$ Large Extent," For the purpose of establishing the dependent variable (youth livelihood outcomes), scores of responses to fifteen questions along a 3point Likert type scale were calculated. The questions assessed the extent to which youth had experienced various aspects of their livelihoods in the previous year to the study. Responses on the scale were coded as: "1=Little Extent", "2=Moderate Extent","3=Large Extent." The lowest and highest possible scores a respondent could have achieved for the 15 questions were 15 and 45 respectively. Using this approach, respondents who attained a range of $15-25$ points were categorized as belonging to the survival level of YLO; those who attained 26-35 points were categorized as belonging to the security level of YLO; respondents who attained 36-45 points were categorized as belonging to the growth level of YLO. The reliability of the research instrument was ascertained by the use of split-half Cronbach's reliability test. This technique involved splitting the scaled questions into two halves and correlating them. The calculated Cronbach's correlation coefficient for the study instruments was 0.83 which was considered acceptable based on the standards set by Cronbach (1951). Ethical approvals were obtained from the relevant research authorities as well as informed written consent from the respondents prior to the study.

\section{RESULTS}

Results showed that males constituted $74 \%$ and females made up $26 \%$, the ages ranged from 18 to 35 years. In terms of marital status, $65 \%$ were single, $34 \%$ were married and one percent were either separated or divorced. Half (50\%) of the respondents had completed high school education, $37 \%$ had tertiary education and $13 \%$ had primary education. In terms of employment status, only $7 \%$ had full-time employment, $62 \%$ were selfemployed, $28 \%$ were unemployed and $3 \%$ were full-time home-makers. The distribution by household headship showed that $66 \%$ were heads of households while $34 \%$ were not.

\section{Uptake and Utilisation of Public, Private and Non-Governmental Financial Interventions}

This study established that the respondents acquired start-up loans from public, private and NGO sources to support their enterprises. These included the public devolved funds in the form of Youth Enterprise Development Fund and Uwezo Fund' private micro-finance institutions and NGOs such as the Ghetto Foundation, a Community Based Organisation in Nairobi. Other sources of finances included Savings and Credit Cooperatives (SACCOs), and mobile money credit facilities from Safaricom M-Shwari and Airtel Money platforms. The value of these loans ranged from one hundred Kenya Shillings (KSh. 100), equivalent to one American dollar (USD \$1.00) on mobile money credit to half a million (KSh. 500,000), equivalent to five thousand dollars (USD \$5,000). Table 1 presents the distribution of uptake and utilisation of loans by respondents. 
East African Journal of Arts and Social Sciences, Volume 2, Issue 1, 2020

Article DOI: https://doi.org/10.37284/eajass.2.1.204

Table 1: Distribution of Uptake and Utilisation of Public, Private, and NGO Financial Interventions

\begin{tabular}{lll}
\hline Variable & Frequency (N) & Percent (\%) \\
\hline Uptake of Loans & 165 & 82 \\
Individual Loans & 36 & 18 \\
Youth Self-Help Group Loans & & \\
Utilization of Loans & 139 & 69 \\
Business Start-up and Expansion & 24 & 12 \\
Educational Purposes (Fees) & 18 & 9 \\
Asset Acquisition & 10 & 5 \\
Health Emergencies & 10 & 5 \\
Basic Needs (Subsistence and House Rent) & $\mathbf{2 0 1}$ & $\mathbf{1 0 0}$ \\
Total & & \\
\hline
\end{tabular}

The results revealed that $82 \%$ of respondents had acquired individual loans to boost their livelihood strategies from public, private and nongovernmental sources while $18 \%$ had accessed the loans as youth self-help groups. The majority of youth $(69 \%)$ acquired loans to start new businesses or expand existing ones, while $12 \%$ and $9 \%$ acquired loans for education purposes such as school fees payment and asset acquisition respectively. Other youths borrowed money in order to attend to health emergencies such as medical bills (5\%) and to meet basic needs such as subsistence and house rent (5\%).
Perceived Impact of Public, Private and NGO Financial Interventions on Youth Livelihood Outcomes

The study sought to investigate the impact of financial interventions on respondent's livelihood outcomes. Respondents were asked to rate the extent to which they attributed the positive change in their livelihood outcomes to the various financial interventions offered by public, private and NGO development actors. The distribution of the perception of the impact of financial interventions by various actors on YLO is presented in Table 2.

Table 2: Distribution of Perceived Impact of Public, Private, and NGO Financial Interventions on YLO

\begin{tabular}{lllll}
\hline Variable & Little extent & Moderate extent & Large extent & Total \\
\hline Public devolved funds (YEDF) & $33 \%$ & $13 \%$ & $54 \%$ & $100 \%$ \\
Private Micro-Finance Institutions & $27 \%$ & $19 \%$ & $54 \%$ & $100 \%$ \\
Youth Self-Help Groups & $13 \%$ & $34 \%$ & $53 \%$ & $100 \%$ \\
Community Based Organisations (CBOs) & $43 \%$ & $20 \%$ & $37 \%$ & $100 \%$ \\
Non-Profit Organisations (NPOs) & $50 \%$ & $16 \%$ & $34 \%$ & $100 \%$ \\
Faith Based Organisations (FBOs) & $57 \%$ & $18 \%$ & $25 \%$ & $100 \%$ \\
\hline
\end{tabular}

The results presented in Table 2 revealed that the three most highly rated financial interventions by the majority of the youths were public devolved funds (54\%, private MFIs (54\%) and youth selfhelp group loans to members (53\%). However, financial interventions by NGOs were not as highly rated as the public and private sources of funding.
Perceived impact of Community-Based Organisations was rated to a large extent by $37 \%$, Non-Profit Organisations by $34 \%$ and Faith-Based Organisations by $25 \%$. This implied that the financial intervention that had the greatest impact on YLO was the Government of Kenya devolved funds in the form of Youth Enterprise Development 
Fund and Uwezo Fund. This was closely followed by private microfinance institutions that provided credit to support youth income-generating activities. This study has also established that the youth self-help groups facilitated their members with financial support in order to improve their livelihood outcomes to a large extent. The NGOs were the least rated development actors who provided financial support for youth livelihood strategies.

\section{Indicators of Youth Livelihood Outcomes}

Indicators of youth livelihood outcomes as adapted from DFID Livelihoods Framework (1999) and the survey instrument generated scores that enabled classification of youth as being in survival, security, or growth YLO levels. The extent to which youth livelihood outcomes had improved as a result of financial intervention is shown in Table 3.

Table 3: Distribution of Perceived Improvement in Youth Livelihood Outcomes Attributed to Financial Interventions

\begin{tabular}{llll}
\hline Perceived improvement in YLO & $\begin{array}{l}\text { Little } \\
\text { extent }\end{array}$ & $\begin{array}{l}\text { Moderate } \\
\text { extent }\end{array}$ & $\begin{array}{c}\text { Large } \\
\text { extent }\end{array}$ \\
\hline 1. Better utilisation of financial resources & $19.0 \%$ & $41 \%$ & $40 \%$ \\
\hline 2. $\begin{array}{l}\text { Increased use of energy efficient domestic fuels } \\
\text { (biogas, LPG \& solar) }\end{array}$ & $35.5 \%$ & $27.9 \%$ & $36.6 \%$ \\
\hline 3. $\begin{array}{l}\text { Benefitted from youth self-help group income- } \\
\text { generating activities and projects }\end{array}$ & $39.2 \%$ & $33.2 \%$ & $27.6 \%$ \\
\hline $\begin{array}{l}\text { Diversification and/or intensification of } \\
\text { livelihood strategies/activities }\end{array}$ & $67 \%$ & $13 \%$ & $20 \%$ \\
\hline 5. $\begin{array}{l}\text { Development of human capital through education } \\
\text { and training }\end{array}$ & $46.7 \%$ & $33.7 \%$ & $19.7 \%$ \\
\hline 6. Reduced dependency on others for livelihoods & $46.9 \%$ & $34.4 \%$ & $18.8 \%$ \\
\hline 7. $\begin{array}{l}\text { Overall, my livelihood outcome has improved in } \\
\text { the past one year }\end{array}$ & $50.0 \%$ & $34 \%$ & $16 \%$ \\
\hline 8. $\begin{array}{l}\text { Improved coping with various shocks and trends } \\
\text { (disease, death, job loss) }\end{array}$ & $50.5 \%$ & $36.4 \%$ & $13.1 \%$ \\
\hline 9. Increase in finances from social capital networks \\
$\begin{array}{l}\text { e.g. youth groups, associations } \\
\text { 10. Higher youth participation in decision making, } \\
\text { leadership roles, employment opportunities }\end{array}$ & $78.0 \%$ & $11.5 \%$ & $10.5 \%$ \\
\hline 11. Acquisition of development loans & $76.0 \%$ & $13.6 \%$ & $10.4 \%$ \\
\hline 12. Improved food security & $73.5 \%$ & $16.5 \%$ & $10.0 \%$ \\
\hline 13. Acquiring more disposable income & $79 \%$ & $14 \%$ & $6 \%$ \\
\hline 14. Increased assets & $80.0 \%$ & $16 \%$ & $4 \%$ \\
\hline 15. Increased savings & $80.5 \%$ & $17 \%$ & $2.5 \%$ \\
\hline & $89.4 \%$ & $8.1 \%$ & $2.5 \%$ \\
\hline
\end{tabular}

Results presented in Table 3 revealed that youth had benefitted substantially from the financial interventions acquired from public, private and
NGOs actors. Half of the respondents reported that their livelihood outcomes had improved to a moderate extent $(34 \%)$ or a large extent $(16 \%)$ due 
to the financial interventions received over a period of one year prior to the study. The indicators of youth livelihood outcomes which recorded scores of improvement to a "Large extent" in rank order were better utilization of financial resources (40\%), use of more energy-efficient domestic fuels (36.6\%), benefits from youth self-help group income-generating activities and projects (27.6\%) and diversification of youth livelihood strategies (20\%). On the other hand, the indicators of YLO that were ranked least were savings $(2.5 \%)$, assets $(2.5 \%)$, incomes (4\%) and food security $(6 \%)$.

\section{Classification of Youth Livelihood Outcomes}

Livelihood outcomes occurred along a continuum of three levels namely Survival, Security and Growth. In this study, youth were classified at Survival YLO level when their greater concern was attaining basic needs and had limited opportunities. Youth were classified at security YLO level when they transited towards more reliable livelihood strategies and interventions while those at growth YLO level could now afford to pursue riskier livelihood strategies such as the establishment of new business or expansion of existing enterprises.

Table 4: Distribution of Youth Livelihood Outcome levels

\begin{tabular}{lll}
\hline Variables & Frequency $(\mathbf{N})$ & Percent $(\boldsymbol{\%})$ \\
\hline Survival Livelihood Level & 105 & 52 \\
Security Livelihood Level & 35 & 18 \\
Growth Livelihood Level & 61 & 30 \\
\hline Total & $\mathbf{2 0 1}$ & $\mathbf{1 0 0}$ \\
\hline
\end{tabular}

According to the results presented in Table 4, the aggregate scores for youth livelihood outcomes indicated that $52 \%$ of the youth were at a survival level, $18 \%$ were at the security level and $30 \%$ were at growth level of youth livelihood outcomes.

\section{Hypothesis Test Results}

The hypothesis stated that there is no statistically significant impact of public, private and NGO financial interventions on youth livelihood outcomes (YLO). The results of the hypothesis test are presented in Table 5.

Table 5: Regression Results for Predictors of Youth Livelihood Outcomes

\begin{tabular}{|c|c|c|c|}
\hline \multirow[t]{2}{*}{ Predictor Variables } & \multicolumn{3}{|c|}{ Estimated Coefficient } \\
\hline & $\begin{array}{l}\text { Odds Ratio } \\
(\beta)\end{array}$ & $\begin{array}{l}\mathrm{Z} \\
\text { Statistic }\end{array}$ & $\begin{array}{l}\text { Significance } \\
(p>Z)\end{array}$ \\
\hline Public Financial Interventions (YEDF, Uwezo) & $0.761^{* *}$ & 2.63 & $0.009 *$ \\
\hline Micro-Finance Institutions & $1.003^{* *}$ & 2.46 & $0.010^{*}$ \\
\hline Youth Self-Help Groups & $1.037^{*}$ & 2.23 & $0.018^{*}$ \\
\hline Non-Profit Organisations & 0.937 & -0.54 & 0.590 \\
\hline Faith Based Organisations & 0.976 & -0.19 & 0.848 \\
\hline Community Based Organisations & 1.074 & 0.51 & 0.607 \\
\hline Pseudo $R$-Squared $\left(R^{2}\right)$ & 0.0561 & & \\
\hline Log likelihood (Iteration 4) & -157.28626 & & \\
\hline LR chi-Square (d.f. $=7)$ & $18.7^{* *}$ & & 0.002 \\
\hline
\end{tabular}

** Significant at $p<0.01$ and $*$ Significant at $p<0.05$ 
The results revealed that there was a significant relationship between funding sources and youth livelihood outcomes. A significant Chi-Square (LR $\chi^{2}=18.7 ;$ d.f. $\left.=7 ; \rho=0.002\right)$ was attained which implied that financial interventions were important variables that influenced youth livelihood outcome levels in the study area. Therefore, the hypothesis posited that there was no relationship between financial interventions and youth livelihood outcomes was rejected. This implied that financial interventions had a statistically significant influence on youth livelihood outcomes. The three significant predictors of YLO in rank order were the Government of Kenya public devolved funds comprised of Youth Enterprise Development Fund and UWEZO Fund $(\beta=0.761 ; p=0.009)$, followed by private micro-finance institutional funding $(\beta=1.003 ; p=0.010)$ and Youth Self-Help Group loans to members $(\beta=1.037 ; p=0.018$. The variables that were not significant predictors of YLO were Non-Profit Organisations, Faith-Based Organisations and Community-Based Organisations. These findings implied that government-sponsored devolved funds (YEDF and UWEZO Fund) had the greatest impact on YLO, followed by loans and credits provided by microfinance institutions and finally sponsorships provided by youth self-help groups to their members.

\section{DISCUSSION}

This study has established that there was a significant relationship between financial interventions from public, private and NGO sources and youth livelihood outcomes. The public and private financial interventions were positive significant predictors of youth livelihood outcomes.

\section{Uptake of Public Financial Interventions}

The study findings identified YEDF and Uwezo Fund as significant predictors of youth livelihood outcomes. It was evident from the results that the rate of uptake of financial interventions by youth was high. The registered youth groups in the sample had accessed start-up loans from the Youth Enterprise Development Fund and Uwezo Fund. The study attributed this to the awareness of government devolved funds at the grassroots level. The majority of youth had met the preconditions for qualifications such as establishment and registration of youth self-help groups. This study concurs with Lagat, Maru, Chepkwony and Kotut (2012) on the uptake of the Youth Enterprise Development Fund and the growth of enterprises at constituency level in Kenya. The researchers reported that increased awareness and uptake of YEDF had a significant effect on the development of youth enterprises in Kenya. This study is also supported by Waruguru et al. (2017) in their research on assessment of the opportunity component of entrepreneurship policy in the YEDF and Uwezo Fund in Kenya. The study revealed that YEDF and Uwezo Fund addressed the opportunity structure in the reduction of administrative burden, business support, and start-up financing for youth enterprises. Bwisa (2011) affirmed that YEDF was established in order to fill the start-up financing gap for people who do not meet the "track record" and collateral security criterion of traditional financiers.

\section{Uptake of Private Financial Interventions}

The study findings identified MFIs as significant predictors of youth livelihood outcomes. Overall, dissemination of information on financial products by MFIs was high partly because industry players were engulfed in stiff competition among themselves as they sought to grow their market share. These findings concur with Amenya, Onsongo and Omwong'a (2011) who established that there was a proliferation of financial service providers who have to compete to persuade clients to utilize their services in Kenya. These findings are supported by Njuguna (2016) who reported that the private sector and in particular micro-finance institutions used aggressive methods to create awareness on their youth-targeted financial products and services. These included myriad strategies such as direct sales by branch staff in the 
local markets, colleges and secondary schools, roadshows and exhibitions, use of exhibition halls at community events, partnership with youthtargeted organisations, internet through their Facebook and Twitter accounts, mobile notifications through short message service (SMS), billboards, flyers, television and radio advertisements. Other modes of awareness creation were through training and seminars for youth group leaders on either internet platforms or face-to-face sessions. Other avenues included events such as the International Youth Day and Ghetto Radio, a local radio station based in Nairobi.

\section{Uptake of NGO Financial Interventions}

The study findings established that the impact of NGOs on Youth livelihood outcomes was not statistically significant. There are several reasons why the NGO sector was not as attractive to the youth as the public and private financial interventions. This finding is supported by Njuguna (2016) who reported that NGOs such as SACCOs and ROSCAs used stringent preconditions for qualifications for small loans. The study observed that SACCOs and ROSCAs allowed loans and deposits only at certain specified intervals such as once a month and in a pre-set amount of contributions. Other limitations included access to a fixed amount of loan that was least likely to fit every group member's investment plan. In addition, the money was not available when one needed it most as in the case of a business startup or expansion because the allocation of the money was done by lottery method. This finding concurs with Siwan and Baland (2002) who revealed that participation in a ROSCA is a strategy a person employs to protect the savings against claims by dependents for immediate consumption.

\section{Impact of public, private and NGO Financial Interventions on Youth Livelihood Outcomes}

As assessment of financial interventions indicated that the greatest impact on youth livelihood outcomes were Government of Kenya sponsored Youth Development Enterprise Fund and UWEZO Fund, followed by Micro Finance Institutions' provision of loans and finally, financial sponsorship of members by the Youth Self-Help Groups in rank order from the highest to the lowest. This is supported by earlier findings that showed that the majority of registered youth groups had accessed state devolved government funds compared to the youths who had accessed formal loans from either microfinance institutions or non-governmental organisations in the study area. The youth reported positive impacts of public and private financial interventions such as increased incomes, improved food security, economic independence and acquisition of entrepreneurial skills. This finding is supported by ANDY (2012) who reported that financial interventions led to increased start-up of micro and small enterprises, job creation, and development of entrepreneurial skills, reduced crime and increased youth participation in community development.

\section{CONCLUSION AND RECOMMENDATIONS}

This study has established that there was a significant relationship between the various financial interventions and youth livelihood outcomes. The results revealed three significant predictors of YLO in rank order as the Government of Kenya devolved funds comprised of Youth Enterprise Development Fund and UWEZO Fund, followed by private Micro-Finance Institutions sponsored funding and youth-driven financial sponsorship of members of the Youth Self-Help Groups. The variables that were not significant predictors of YLO were Non-Profit Organisations, Faith-Based Organisations and Community-Based Organisations. These findings implied that government-sponsored devolved funds (YEDF and UWEZO Fund) had the greatest impact on YLO, followed by loans and credits provided by microfinance institutions and finally sponsorships provided by youth themselves through their selfhelp groups as compared to NGOs, (NPO, CBO and 
FBO) sponsored financial interventions. This study concluded that the YEDF and Uwezo Fund, MicroFinance Institutions and Youth Self-Help Groups (YSHG), sponsored financial interventions had significant positive impacts on youth livelihood outcomes. It is therefore recommended that there is a need for more youth-focused financial interventions by both the government, private and NGO actors in order to improve youth livelihood outcomes. Furthermore, active participation by the youth in their development process is paramount for sustainable livelihoods to be achieved.

\section{ACKNOWLEDGEMENTS}

We wish to appreciate the support of the youth who participated in this research.

\section{AUTHORS' CONTRIBUTIONS}

The first and second authors participated in the research process from research conception, to the development of research tools, data collection, analysis and writing of the research report.

\section{REFERENCES}

African Union Commission. (2006.) African Youth Charter. Retrieved 8 July, 2020, www.un.org/en/africa/osaa/pdf/au/african_you th_charter_2006.pdf

ANDY. (2012). Baseline Survey on the impact of Youth Enterprise Development Fund and the National Development Fund for Persons with Disabilities. Nairobi: Action Network for the Disabled.

Amenya, S., Onsongo, O. \& Omwong'a, M. (2011). An Analysis of the challenges facing YEDF in Kenya. A paper presented at the AIBUMA 2011 Conference held at KICC in Nairobi, Kenya.

Atsiaya, S. A. (2020). Role of SACCOs on financial inclusion and supporting health care in Africa.
Retrieved

from

https://www.un.org/development.

Bwisa, H. (2011). Entrepreneurship Theory and Practice. Nairobi: The Jomo Kenyatta Foundation.

CARE (2011), Microfinance in Africa: State-ofthe-Sector Report. Nairobi: CARE. Retrieved 8 July, 2020 , www.care.org/sites/default/files/documents/M F-2011-CARE-Access Africa-Closing-theGap.pdf.

Cunningham, W., Sanchez-Puerta, L. \& Wuermli, A. (2010). Active Labor Market Policies for Youth: A framework to Guide Youth Employment Interventions. Washington DC: The World Bank. Retrieved from www.siteresources.worldbank.org/INTLM/21 45781103128720951/22795057/EPPNote 16_Eng.pdf.

DFID (1999). Sustainable Livelihoods and Poverty Elimination. London: Department for International Development.

FinAccess (2009). National Survey 2009, Dynamics of Kenya's changing financial landscape. Nairobi: FinAccess.

Institute of Medicine (2002). Community programmes to promote youth development. Children, Youth and Environments, Vol. 15, No. 2, pp.1545-2250.

Kiraka, R.N. Kobia, M. \& Katwalo, A, M. (2013) Micro, small and medium enterprise growth and innovation in Kenya: A case of the women enterprise fund', Investment Climate and Business Environment (ICBE) Research Fund Report No. 47/13.

Lagat, C., Maru, L., Chepkwony, J. \& Kotut, S. (2012) Youth Enterprise Development Fund and growth of enterprise at constituency level in Kenya. European Journal of Economics, 
Finance and Administrative Sciences, Vol. 54, No. 1, pp. 175-182.

Lewis, D. \& Kanji, N. (2009). Non-governmental organizations and development. Retrieved from https://www.researchgate.net $10.4324 / 9780203877074$.

Maisiba, F. M. and Gongera E. G. (2013). The Role of Youth Enterprise Development Fund (YEDF) in Job Creation: A Case of Dagoretti Constituency, Nairobi County, Kenya. Research Journal of Finance and Accounting, 4 (12), 340-289.

McKee, T. (1989). Micro-level strategies for supporting livelihoods, employment and income generation for poor women in the third world: The challenge of significance. World Development, Vol. 177, No. 7, pp. 993-1006.

Njonjo, S.K. (2010). Youth Fact Book: Infinite Possibility of Definite Disaster? Institute of Economic Affairs and Friedrich-Ebert Stiftung, Elite Pre-Press Limited, Nairobi.

Njuguna, C. W. (2016). Predictors of youth livelihood outcomes in Kamukunji Sub-County, Nairobi County. Kenya. Unpublished Doctoral Thesis. Kenyatta University.

Ogolo, A. (2009). Devolved initiatives in Kenya, a blessing or a curse. Retrieved 19 July 2020, www.internationalpeaceandconflict.org/forum /topics/devolved-fund initiatives

Omolo, J. (2010). Youth Unemployment in Kenya. In: A Kitonga \& K.S. Njonjo (Eds.), Youth Research Compendium. Youth: Infinite Possibility or Definite Disaster? Nairobi: Institute of Economic Affairs.

Omolo, O. J. (2011). Labour and Employment Inequalities in the Context of the East African Regional Integration Process. In: Society for International Development. East African Integration: Dynamics of Equity in Trade,
Education, Media and Labor. Nairobi: Ascent Limited.

Siwan, A. \& Baland, J. (2002). The Economics of ROSCAs and Intra-household Resource Allocation. The Quarterly Journal of Economics, 117 (3), 963-995.

United Nations Economic Commission for Africa and African Union Commission, (2010). Economic Report on Africa 2010: Promoting high-level sustainable growth to reduce unemployment in Africa. UNECA: Addis Ababa, Ethiopia

United Nations Development Programme (2013) Kenya's Youth Employment Challenge. New York: United Nations.

United Nations Development Programme (2010). Kenya National Human Development Report 2009: Youth and Human Development Tapping the Untapped Resource, Kenya. Nairobi: United Nations.

United Nations Economic Commission for Africa and African Union Commission (2010). Economic report on Africa 2010: Promoting high-level sustainable growth to reduce unemployment in Africa. Addis Ababa, Ethiopia: UNECA.

USAID (2012a). Introduction to programming policy. Washington, DC: USAID.

USAID (2012b). Supporting youth: An inventory of funders, implementers, and research institutions. Prepared by JBS International Inc., Washington, DC: USAID.

USAID (2013). State of the field report: Examining the evidence in youth workforce development. Washington, D.C.: USAID.

Uwezo (2014). About Uwezo Fund. Retrieved 30 June 2020, www.uwezo.go.ke/ 
East African Journal of Arts and Social Sciences, Volume 2, Issue 1, 2020

Article DOI: https://doi.org/10.37284/eajass.2.1.204

Waruguru, M., Bwisa, H. \& Kihoro, J. (2017). An

Assessment of the Opportunity Component of Entrepreneurship Policy in the Youth, Women, and Uwezo Funds in Kenya. International Journal of Academic Research in Business and Social Sciences, Vol. 7, No. 1, 283-305.

YEDF (2006). Youth Enterprise Development

Fund. Retrieved from

https://www.youthfund.go.ke. 